\title{
The importance of professional competencies in the development of emotional intelligence
}

\author{
Ignacio Danvila del Valle \\ Universidad Complutense \\ idanvila@ccee.ucm.es \\ Miguel Ángel Sastre Castillo \\ Universidad Complutense \\ masastre@emp.ucm.es \\ Edmundo Marroquín Tovar \\ Universidad Panamericana \\ emarroq@up.edu.mx
}

Resumen: El concepto de Inteligencia Emocional se ha convertido en uno de los tópicos más analizados tanto por académicos como por profesionales de recursos humanos $y$ dirección de empresas. Esto se debe al impacto que tiene en los logros personales $y$ profesionales. La importancia de poseer las adecuadas competencias personales y profesionales suele conllevar mayores garantías de éxito en el ámbito laboral. Este artículo realiza una revisión de este concepto y detalla los principales modelos de competencias, asi como las principales teorías, instrumentos de medición y efectos que puede tener en la vida profesional la inteligencia emocional. Por último, se esbozan un conjunto de conclusiones y líneas de investigación relacionadas con este tema.

Palabras clave: Inteligencia emocional, competencias emocionales, rendimiento, inteligencia cognitiva.

Abstract: The concept of emotional intelligence has been subject to considerable analysis by both academics, and buman resource and business management professionals. Because of their impact on personal and professional achievements, the proper personal and professional competencies are of great importance because they ensure greater success in the workplace. This article reviews this concept and 
Ignacio Danvila del Valle, Miguel Ángel Sastre, Edmundo Marroquín

details the main competency models and theories, measuring instruments, and possible effects of emotional intelligence on professional development. Finally, it outlines some conclusions and related lines for future research.

Keywords: Emotional intelligence, emotional competences, performance, cognitive intelligence. 


\section{Introduction}

The term «emotional intelligence» (EI) currently arouses great interest in both academia and the professional world. However, it also generates some controversy because the concept is sometimes used superficially (Danvila and Sastre, 2010). In 1920, Thorndike introduced the concept «social intelligence» to refer to «the capacity to understand and manage men and women, boys and girls - to act wisely in human relationships» (Law et alii, 2008).

In the 60 s, the term «emotional intelligence» was occasionally used by literature critics (Van Ghent, 1961) and in psychiatry (Leuner, 1966). In the eighties, Payne (1986) used the term more systematically. Gardner (1983) included the term "personal intelligence» in his fundamental work on the theory of multiple intelligences. Specifically, according to this author, personal intelligence consisted of intra-personal intelligence (that is, the knowledge of the internal areas of a person) and inter-personal intelligence (the basic capacity to notice differences between people, in particular the contrast of different moods, temperaments, motivations and intentions (Gardner, 1993).

By the nineties, the term EI had been explicitly defined (Salovey and Meyer, 1990), a theory had been developed and criteria for measuring it established. In this study, the authors defined EI as a subset of social intelligence that involves the capacity to control one's own feelings and emotions, and those of others, to discriminate between them and use this information to guide thinking and actions.

These authors reviewed the concept years later and drew up a more specific definition. EI became «the capacity to perceive with precision, assess and express emotions; the capacity to find and/or generate feelings when these facilitate thinking and the capacity to understand and control emotions to promote emotional and intellectual growth» (Mayer and Salovev, 1997: 5).

Goleman (1995) defined EI, by exclusion, as any personal desirable characteristic that is not represented by cognitive intelligence. He established two categories of personal intelligence, both of which were complementary. In fact, the emergence of this concept is largely due to the inter-relation of knowledge and emotions, and explains the different levels of success in different areas of life. Thus, for most authors, knowledge or cognitive intelligence may not be the only predictor of success (Dulewicz de Higgs, 2000; Cherniss, 2001, Mandell and Pherwani, 2003). For Boyatzis and Saatcioglu (2008), empirical research (Boyatzis, 1982; Luthans et alii, 1988; Howard and Bray, 1988) has shown that the possibility to predict the performance of a leader, manager or professional depends on a series of competencies that can be grouped into three categories: 
1. Cognitive intelligence competencies such as the systems of thought.

2. Emotional intelligence competencies or intra-personal skills such as the capacity to adapt.

3. Social intelligence competencies or inter-personal skills such as networking.

The concept of competence was initially defined as the ability of individuals to respond to demands in their environment and this ability provides satisfaction or a sense of efficacy (White, 1959). In the same year, Penrose suggested that a company could raise revenue by having not only the best resources but also distinctive competencies, which allow these resources to be used to the best advantage (Nordhaug and Gronhaug, 1994:91).

McClelland (1973) preferred to call them «competencies» instead of "personality variables» to emphasize that they can be learned. Later on, he suggested grouping the competencies by results and distinguishing professional competencies from social competencies.

Boyatzis (1983) defined the term «competency» as «an individual's underlying characteristic causally related with an effective or superior performance.» Therefore, he linked effective performance to job requirements and organizational context, opening the area to define competencies contingently. In this regard, each business may define its own competencies based not only on superior performance but also on considering these two factors: job requirements and organizational context.

Later on, Spencer and Spencer (1993) took up Boyatzis' proposal (1983) to define a competence as «an individual's underlying characteristic causally related with an effective or superior performance in reference to a criteria». By referring it to criteria, they established the basics to be able to measure, grade, compare, etc. They also proposed to classify the competencies by categories.

Levy-Leboyer (1997: 13) defined competencies as «codes of conduct that some people manage better than others, and make them effective in a given situation.» Her definition is quite general because she tries to embrace different meanings of the concept of competency: authority, training, competition, skill, responsibility and sufficiency.

Beyond knowledge and competencies, the additional necessary ingredient for an exceptional performance seems to be the desire to use one's own talent (Boyatzis and Sala, 2004; Boyatzis, 2006).

These three domains of talent - knowledge, competencies and motivational type controllers, help to show what a person can do (knowledge), how it can be done (competencies), and the reason for doing it (values, motivations or unconscious dispositions). 
The intra-personal and inter-personal skills that define EI are clear predictors to success in every aspect. Jamali, Sidani and Abu-Zaki (2008) argue that research confirms that people with higher levels of EI are more successful in life (Bar-On, 1997a), obtain greater professional success (Dulewicz and Higgs, 1998; Weisinger, 1998), feel less job insecurity (Jordan et alii, 2002), work more efficiently (Higgs and Rowland, 2002; Prati et alii, 2003), are more adaptable to stressing events (Nikolaou and Tsaousis, 2002) and better cope with strategies (Bar-On et alii, 2000).

Aware of the importance of emotional intelligence, our goal here is to carry out a specialized literature review, formulating the questions that have been asked, discussing the models by which competencies can be achieved and relating EI with other similar concepts. We will also analyze the current main theories, the measuring instruments generally used and their personal or professional effects on people's lives.

\section{Criticism of emotional intelligence}

Consultants use EI as an instrument that is very well accepted. By correctly using competencies, EI can increase performance and productivity (Cherniss and Adler, 2000: 10). However, no independent and systematic analysis has been carried out to support this statement (Thi Lam and Kirby, 2002).

Hence, the concept of EI has been strongly questioned. The severest critics have referred to EI as more «like a myth than science» (Matthews, Zeidner and Roberts, 2002: 547).

In many cases, the publications on EI are more commercial literature than scientific research (Davies et alii, 1998).

For these reasons, there is lively debate about what EI really provides. Some authors say that EI is just a new word for old concepts and measures; others defend its validity (Van Rooy, Viswesvaran and Pluta, 2005).

\section{Relation of emotional intelligence with other terms}

Sometimes, the increasing use of the term 'emotional intelligence' by both academic studies and commercial literature has been compared with concepts that have no link to emotions or intelligence. 
In this section we will analyze the relationship of EI with other similar concepts that are occasionally related or overlapped, like general intelligence or personality.

\subsection{EI - general intelligence or cognitive capacity relationship}

Intelligence is the capacity to acquire basic knowledge and use it in new situations. Itcan be measured and, in fact, «the general intelligence measured by IQ tests is the most effective known predictor of individual performance, either at school or at work» (Gottfredson, 1998: 24).

Accordingly, O'Reilly III and Chatman (1994) and Ferris, Witt and Hochwarter (2001) state that general mental capacity (GMC), or its equivalent, general intelligence or the $\mathrm{G}$ factor, has provided interesting evidence to predict important results in job performance, successful training and professional achievement. Law et alii (2008) specifically focus on the performance of complex tasks that require considerable academic preparation (Landy, Shankster and Kohler, 1994).

A number of studies have demonstrated that the relation between EI and cognitive capacity depends on which model of competencies and which method is used to measure EI (Van Rooy, Viswesvaran and Pluta, 2005).

The main competency models and, particularly, the EI capacity model maintain that EI should be considered as a type of intelligence, akin to verbal or spatial intelligence. Consequently, EI and cognitive capacity must be moderately associated (Roberts et alii, 2001).

On the other hand, the mixed EI model does not support this argument. Therefore, EI metrics based on the mixed model do not have a theoretical foundation that suggests a correlation between EI and cognitive capacity, as is affirmed by the studies of Newsome, Day and Catano (2000); or Brackett and Mayer (2003).

According to Law et alii (2008), since EI is more related to the affective and motivational areas of the human mind, it is an additional factor that incrementally contributes to predict job performance with more precision than the general mental capacity factor, which is only related to the cognitive manifestation of the mind. As far as the theoretical framework is concerned, EI performance analysis goes beyond GMCs. 


\subsection{Relationship of EI to personality}

The metrics used in EI may overlap, or be mistaken with, existing personality scales, and they can also be highly correlated to them (Bar-On, 1997a; Davies et alii, 1998; Newsome, Day and Catano, 2000; Brackett and Mayer, 2003).

Most EI academic critics suggest that EI only extracts different facets of personality. In other words, they say that EI is just a combination of emotional stability and intelligence. Empirical findings, however, do not support such a statement.

Van Rooy, Viswesvaran and Pluta (2005) show that EI correlations with personality factors depend on the competency model used. They pointed out that Dawda and Hart (2000) used the EQ-I self-report (Bar-On, 1997a) and all of the big five personality factors, and had correlations above 0.40 with all of them except openness to experience. Other studies have also used mixed metric models and have found high correlations among the big five personality factors. The general consensus is that there is a significant overlap between both models (Davies, Stankov and Roberts, 1998).

The relationship between EI and personality takes a different form when a metric based on capacity is used, instead of the mixed model. Therefore, it seems that the EI metrics based on the capacity model do not show such a strong link to personality as the metrics based on the mixed model do.

This different relationship suggests that both models measure relatively different realities.

In this context, an analysis needs to be made of the main competency models for professional competencies or used at jobs that have an efficient or superior performance. Likewise, these competencies are the foundation that supports most instruments for measuring emotional intelligence.

\section{Main competency models}

Given the subjectivity involved in their analysis, competency models have different perspectives. Velasco (2009) has identified five schools of thought: behaviorist, functionalist, constructivist, holistic and human capital. The behaviorist perspective considers competence as an underlying combination of skills, knowledge and attitudes. The functionalist perspective is results- and target-oriented, and uses competencies to measure results, task performance and personality characteristics. The constructivist perspective defines competence as the capacity and the knowledge to do. The holistic perspective defines competence 
as a combination of knowing and understanding (knowledge), knowing how to act (skills) and knowing how to be (behaviors and ethical values); this perspective considers the influence of ethical values on personal attitudes, too. Finally, the human capital perspective defines competence as a set of skills, capacities and knowledge. We think that the behaviorist and holistic perspectives are the most appropriate for our analysis since both distinguish knowledge, skills and attitudes.

Spencer and Spencer (1993) developed a competency model to analyze the relationship between competencies and efficient or superior performance. With this goal, they considered twenty competencies and grouped them into the following six categories: Achievement and Action, Helping and Human service, Impact and Influence, Managerial, Cognitive and Personal Effectiveness.

The set of «Achievement and Action» competencies gathers competencies related to excellence levels. They are oriented to results, efficiency and standard compliance.

- Achievement orientation: This relates to task accomplishment and the achievement of excellence, either to improve levels of self-performance, achieve a proposed goal or relative to the performance of others.

- Concern for order, quality and precision: This relates to reducing context uncertainty.

- Initiative: This relates to doing more than expected to improve results or to avoid future problems.

- Information seeking: This relates to interest in increasing self-knowledge. It involves making the effort to obtain information.

The set of «Helping and Human service» competencies includes competencies related to considering others' interests and needs, and working to help to achieve them.

- Interpersonal Understanding: This involves the desire to understand the ideas, feelings and worries of others. It implies the skill to listen and to perceive nonverbal language.

- Client Service Focus: This involves making an additional effort to comply with client's needs, as well as attending their complaints.

The set of «Impact and Influence» includes competencies related to effects of actions on others, seeking the benefit of organizations and others. These competencies are:

- Impact and Influence on others: This relates to the intention to persuade, convince or influence others, to get them to support their own initiatives. 
- Organizational Awareness: This relates to the skill to understand power relations in the organization - who makes the decisions and who influences them.

- Relationship Building: This relates to establishing and maintaining friendly relations with others who are, or could be, useful for achieving goals.

The set of «Managerial» competencies pursues certain effects on subordinates:

- Developing others: This consists of teaching or helping others.

- Directiveness: This refers to getting others to execute instructions or orders, seeking the benefit of the organization and its people.

- Teamwork and cooperation: This implies working with others, being part of a team and working together, with or without a team leader, but with the desire to participate actively and facilitate collaboration.

- Team leadership: This refers to the intention to lead a group or team, with or without formal authority.

«Cognitive» competencies are those competencies that an individual needs understand a situation, task, problem or opportunity. They are the following:

- Analytical Thinking: This refers to the ability to understand a situation, divide it into smaller parts, draw causal implications systematically and establish priorities.

- Conceptual Thinking: This refers to understanding a situation by joining its parts, visualizing the complete image, and identifying patterns and connections.

- Technical/Professional Expertise: This refers to mastering technical or professional activities related to a job position, and being able to transfer knowledge to others.

The competencies in the set of «Personal Effectiveness» are those related to an individual's maturity to work with others. These competencies control the effectiveness of a person under pressure or difficulties. The competencies that form this group are:

- Self-control: This refers to maintaining emotions under control and suppressing negative reactions against others.

- Self-confidence: This refers to an individual's belief in his/her capacities to perform a task.

- Flexibility: This refers to knowing how to adapt and how to work effectively in a variety of situations. It involves understanding and appreciating different perspectives, being prepared to change and accepting changes when necessary. 
- Organizational Commitment: This refers to the intention of aligning behaviors and actions with organizational needs, priorities and goals.

The competency model proposed by Spencer and Spencer (1993) was particularly relevant, since it contributed to the design of competency-based jobs and tests for determining whether applicants for a position had the appropriate competencies and, if so, what level they had acquired.

Spencer and Spencer (1993) argue that the performance level is usually a point along the normal distribution of the performance of all the employees in an organization.

\section{Figure 1. Economic Value Added by Superior (+1 SD) Performance}

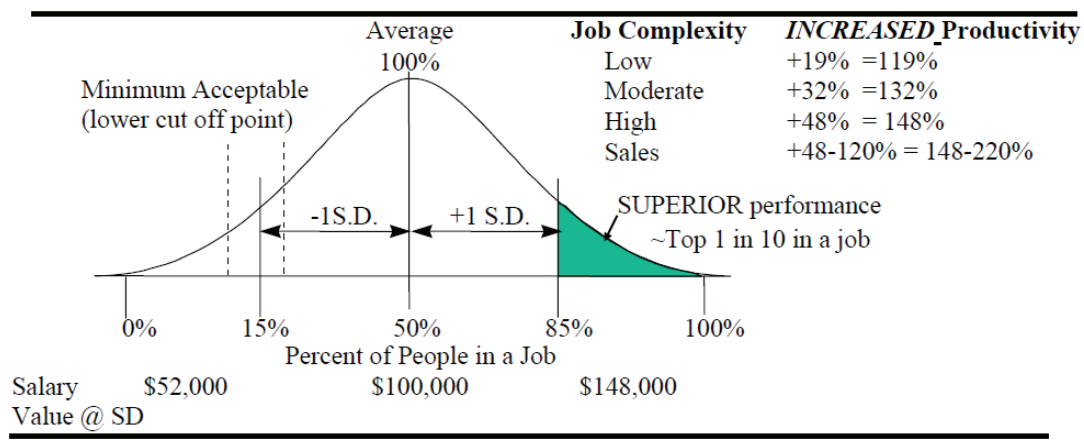

Source: Spencer Lyle M. (2003) How competencies create economic value in Berger, L. A. \& D. R Berger Eds (2003) The Talent Management Handbook, New York, NY: McGrawHill.

Figure 1 shows three reference points: minimum acceptable, average and high. The minimum acceptable performance is the lower limit that the organization tolerates and is located below average. The average performance is the mean normal distribution. High performance is located above the mean.

The group of people with high performance produces greater economic value added. According to Spencer and Spencer (1993), this group includes approximately $10 \%$ of employees, who can be between $48 \%$ and $120 \%$ above average. Senior management should take special attention of this group of workers when reviewing training and career plans. It would be useful for management to analyze the set of competencies of this above-average-performance group and develop a training plan so that they can acquire those competencies and increase their overall performance. Spencer and Spencer (1993) consider that the characteristics that predict high performance are «differentiators», since they statistically differentiate high performance from average performance. They also 
argue that a predictive variable (independent), which consistently measures a competency, statistically predicts a performance variable (dependent).

The competency model that is currently being used in the United States does not use the concept «competency» but refers to it when making the following category differentiation (Shoikova and Krumova, 2010):

- Worker characteristics: skills, interests, values and work styles

+ Worker requirements: skills, knowledge and training

- Required experience: experience and training, capacities to acquire basic and transferable skills, and certifications

This last classification is the most widespread and up to date. The United States government has invested millions of dollars on each version, in an attempt to standardize measures and evaluations over a wide variety of jobs. However, the model focuses on evaluation and certification, not on management.

Boyatzis (2007) states that competencies may be developed in adults to help them to be more effective. Edwards (2008) designed and applied a competency model in a social service agency to improve management performance. Also, Sanghi (2009) analyzed four cases that used a competency model to train their personnel, and considered that the implementation of any strategy depends on the competencies of the employees.

Levy-Leboyer (1997) points out that the first thing to be done is to analyze particular jobs, identify the activities and behaviors they require, define the proper competencies for the job and design the corresponding evaluation methods. Once the required competencies have been defined and the method for evaluating them established, an individual training plan can be designed for each employee so that they can all acquire the competencies they need.

To conclude this analysis of competency models it should be pointed out that the competencies required to achieve high performance are not universal; they depend on particular contexts.

\section{Main theories of Emotional Intelligence}

The main EI theories were forwarded by Bar-On (1988, 2000), Salovey and Mayer (1997), and Goleman (1998a) (Jamali, Sidani and Abu-Zaki, 2008) (Table 1). Bar-On (1988) suggested that the term «emotional coefficient» (EQ) was analogous to the term intellectual coefficient (IQ). Subsequently (1997b), he went on to define his model using five main social and emotional skills intrapersonal skills, interpersonal skills, adaptability, stress management and 
mood - which influence the general capacity of an individual to deal effectively with his/her requirements (Goleman, 2001).

A decade later, Salovey and Mayer (1997) developed a model with a cognitive focus, highlighting specific mental skills for recognizing and classifying emotions (Goleman, 2001). Their model consists of four skill levels, of differing complexities and based on the processes that involve emotions and cognitions.

Goleman (1998b) presented an EI theory based on competencies that includes a set of affective and cognitive skills. He based his theory on the competencies required to perform a job. He identified five dimensions of emotional intelligence - self-consciousness, self-control, self-motivation, empathy and social skills which he classified into two main categories: the personal competency to deal with oneself, and the social competency to deal with others (Goleman, 1995).

Table 1: Main EI theories and the competencies that define them

\begin{tabular}{|l|l|l|}
\hline \multicolumn{3}{|c|}{ Emotional Intelligence Skills } \\
\hline Bar-On (1988) & \multicolumn{1}{|c|}{ Salovey and Mayer (1997) } & \multicolumn{1}{|c|}{ Goleman (19986) } \\
\hline+ Intrapersonal skills & + Emotional perception & Personal competencies on self \\
+ Interpersonal skills & + Use of emotions to & treatment: \\
+ facilitate thinking & + Self-consciousness \\
+ Stress management & + Understanding of & + Self-control \\
+ Mood & emotions & + Self-motivation \\
& + Emotion management & $\begin{array}{l}\text { Social competencies on } \\
\text { treatment of others: }\end{array}$ \\
& & + Empathy \\
& & \\
\hline
\end{tabular}

Source: Author

\section{Instruments to measure Emotional Intelligence}

Because of the conceptual discrepancies surrounding Emotional Intelligence, it is especially necessary to have reliable and valid measuring instruments. These discrepancies also emerge when these measuring instruments are used (Opengart, 2007). The main approaches to measuring EI are (Danvila and Sastre, 2010):

- Those who evaluate EI through goal performance tests, since they consider EI to be a sound, defined set for processing emotions and skills (Mayer and Salovey, 1997; Mayer et alii, 2000). 
- Those who measure EI using self-report methodologies, since they see EI in terms of multiple aspects of personal performance (Goleman, 1995; Bar-On, 1997a; Boyatzis, Goleman and Rhee, 2000).

- Those who consider EI as a measure of the observer's evaluation (Mayer et alii, 2000).

In the first group, the most used measurement instruments are EIMS and MSCEIT, both developed by Mayer et alii (2000). These authors developed a capacity test entitled Emotional Intelligence Multifactorial Scale (EIMS) that had 12 EI sub-scales, and demonstrated that EI, according to EIMS, complies with proper standards of a kind of intelligence and is a different concept to social intelligence (Wong and Law, 2005).

Mayer, Salovey and Caruso's Emotional Intelligence Test (MSCEIT) can also provide an overall score of EI. Mayer et alii (2000) state that mental capacity can be reliably measured and that the internal consistencies are comparable with those of other standardized intelligence tests.

These authors argue that skills tests are the best reference in EI research because they measure the real capacity for good performance.

In the second group, a well-known self-report tool was used: Bar-On's EQI, or Emotional Quotient Inventory. This measure provides an estimate of emotional and social intelligence. It was developed to measure this particular construct and not personality traits or cognitive capacity (Bar-On, 2000).

Accordingly, Wong and Law (2002) developed a self-report measure called the Wong and Law Emotional Intelligence Scale (WLEIS), which proved to have good convergent and discriminant validity (Law et alii, 2004). Using four EI dimensions, it is different from such related constructs as personality factors or other types of cognitive intelligence (Law et alii, 2008).

The third group used the observer's evaluation and measured the individual's reputation, and not necessarily his/her skills (Mayer et alii, 2000). The best known of these methodological tools is the ECI or Emotional Competence Inventory, which combines the self-report with the observer's rating. The ECI is based on competencies developed by Goleman, and organized in groups. This instrument has been reviewed several times to increase its reliability. 


\section{The effects of Emotional Intelligence on professional life}

In recent years, numerous studies have been published on the impact of EI on the work place (Wolff et alii, 2002; Prati et alii, 2003; Dulewicz and Higgs, 2004; Voola et alii, 2004). Many of these studies attempt to determine whether people with a higher level of EI deliver better results. The results confirm that EI may contribute to better individual and organizational performances (Turner $y$ Lloyd-Walker, 2008; Hopkins y Bilimoria, 2008).

The results of various empirical studies prove that this relationship exists. For instance, Boyatzis (1982), in a study of top managers from 12 different organizations, stated that those with a greater capacity for self-evaluation clearly achieved a higher performance. Spencer and Spencer (1993) proved that those managers with the highest sales figures are the ones who try to develop others and reinforce their capacities. Watkin (2000) highlights EI as the most important factor for better performance in all top management position jobs, while Longhorn (2004) suggests that there is a relationship between general managers' EI and their performance, measured by the score on the evaluation of the administrator's performance, the output of benefits under his/her control and customer satisfaction.

However, this positive relationship is not limited exclusively to top management. The employees who are «smart» with their emotions are usually more efficient and effective in their interactions with their work environments and with their coworkers, (Hochschild, 1983; Sutton, 1991).

Elaborating on this relationship, several studies emphasize its importance regarding the effect on traditional intelligence. For instance, research by Van Rooy and Viswesvaran (2003) states that cognitive capacity only counts for $25 \%$ of the variation in work performance, while Goleman (1998b) finds that $67 \%$ of the skills regarded as being essential for efficiency were emotional skills, and Chen et alii (1998) estimate that EI represents $85-90 \%$ of the success of leaders in organizations.

At an organizational level, McClelland (1998) found that those organizations with a wide set of EI competencies related to self-motivation, social conscience and social skills performed much better than the average of their groups. More specifically, they exceeded annual income targets by $15 \%$ or $20 \%$. Similarly, Dulewicz and Higgs (1998) assess the impact of EI on the variance in organizational progress to be $36 \%$, while the intelligence quotient explains only 27 percent. 
The effect of EI does not merely improve performance. Its influence extends to the satisfaction that individuals feel with their jobs and, in general terms, how they respond to change and commitment to the organization (Carmeli, 2003; Vakola et alii, 2004).

Other research has analyzed the key competencies for job satisfaction and professional success. According to Opengart (2007), the key competencies are leadership, self-consciousness, empathy, and sense of humor or stress management. It is clear that these competencies are related to EI. Leadership is probably the competency that has most been studied in relation to success, and with a clear link to EI (Goleman, 1998a and 1998b; Mandell and Pherwani, 2003; Prati et alii, 2003; Turner and Muller, 2005; Strang, 2007).

Numerous studies have shown that the EI factors may predispose individuals to becoming transformational leaders and motivating their followers. True leaders are those who can best recognize and manage their own emotions and those of others, which implies greater levels of success (Ashkanasy and Lawrence, 2002).

\section{Explanatory factors of Emotional Intelligence}

While some studies have analyzed aspects that are explained by EI, others have focused on understanding the factors that explain EI. They have focused on socio-demographic variables such as age, experience and gender.

\subsection{Age}

Some studies indicate that age does not have a significant effect on EI (Cakan and Altun, 2005). Others, however, show a direct link between age and EI levels. Bar-On (2000) proved that older individuals obtain a higher rate on EI, which suggests that EI is improved by life experiences.

Despite this, the relation between age and EI might not be linear. An empirical study on EI levels of Indian executives (Punia, 2002) points out that the EI level increases with age, but only up to a certain level, after which it begins to diminish. Therefore, many emotional skills might decrease at a certain age.

\subsection{Experience}

Numerous studies point out that EI levels increase with experience and position within the organization (Chen et alii, 1998; Goleman, 1998a and 1998b). Nevertheless, this has yet to be empirically proved. Similarly, the importance of EI at work increases as people move up in their organization (Fatt, 2002). 
Van Der Zee (2004) undertook an interesting empirical study, whch showed that board members scored more highly than a reference group on eleven out of fifteen EI dimensions.

\subsection{Gender}

The relation between EI and gender has also received considerable attention in recent years, although the results have been inconclusive.

Mandell and Pherwani (2003) found a significant difference in EI scores between men and women, with women having higher scores. Their results suggest that women seemed more capable of controlling their emotions and those of others than men. These results supported the results of Mayer and Geher (1996), Mayer et alii (2000), Ciarrochi et alii (2000), Mandell and Pherwani (2003), Boyatzis and Sala (2004), and Brackett et alii (2006), which showed higher scores for women with different measures of EI.

However, the abovementioned studies contrast with the results of other authors (Goleman, 1998a; Bar-On, et alii, 2000; Petrides and Furnham, 2006; Nikolaou and Tsaousis, 2002; and Cakan and Altun, 2005), who argue that there is no difference in overall EI scores among men and women.

The problem may lie in treating differences in a global manner and not just from a qualitative perspective.

Although men and women might have the same average level of EI, several studies state that there may be differences when different competencies are considered. Women usually score higher in self-consciousness and empathy, while men usually score higher in self-regulation. Bar-On (1997b) reveals that women are more aware of their emotions, show more empathy and relate better, while men are more skilled in management and the regulation of emotions.

In this regard, although Fatt (2002) found no differences between men and women in measures such as comprehension and regulation of emotions, he found that men do score higher in identification and use of emotions.

\section{Conclusions}

Emotional intelligence is a controversial concept that has been subject to considerable recent research by a number of academics, business experts and the world of consulting. Although it has been strongly questioned because of the lack of empirical support, emotional intelligence has become popular in a short period of time, and has been the object of increasing study. 
A significant amount of this concern has been aroused by the increasing evidence that the traditional predictor of success at work - knowledge and general intelligence - is insufficient. Most authors consider that knowledge and cognitive intelligence cannot be regarded as the only predictors of success (Danvila \& Sastre, 2010).

Cognitive and emotional intelligence might be considered complementary and the rise of the concept of EI is largely due to the fact that knowledge and emotions are interrelated, and may explain different levels of success in various areas of life, including the workplace.

Worker's emotions might influence their job performance. These skills are crucial and, as argued by Opengart (2005), human resource professionals have the responsibility to help employees develop their capacities.

Moreover, those who are responsible for human resources in organizations must be aware of the competencies their employees have and, if necessary, establish and implement a training plan. This plan should aim to provide employees with the competencies they do not have at the necessary level of proficiency.

Numerous research studies show that EI capacities and competencies have a direct impact on leadership skills (at least on transformational leadership).

If leadership capacity is directly influenced by an individual's competencies, which, by extension, have a direct effect on his/her professional results, any research carried out in an attempt to define this concept more clearly and to design training plans that enable workers to develop competencies is fully justified.

\section{References}

Ashranasy, N. M. and Daus, C. (2002). «Emotion in the workplace: The new challenge for managers». Academy of Management Executive, 16 (1): 76-86.

BAR-ON, R. (1988). The development of an operational concept of psychological wellbeing. Grahamstown: Rhodes University.

- (1997a). Bar-On Emotional Quotient Inventory: Technical manual. Toronto: Multi-Health Systems.

- (1997b). «Development of the Bar-On EQ-Iः a measurement of emotional and social intelligence». Paper presented at the 105th Annual Convention of the American Psychological Association. Chicago.

- (2000). «Emotional and social intelligence: insights from the emotional quotient inventory (EQ-I)», in BAR-ON, R and Parker, J. (2000). The Handbook of Emotional Intelligence. San Francisco: Jossey-Bass. 
Bar-On, R.; Brown, J; Kirkcaldy, B. and Thome, E. (2000). «Emotional expression and implications for occupational stress: an application of the emotional quotient inventory (EQ-I)». Personality and Individual Differences, 28: 1107-1118.

Boyatzis, R. E. (1982). The Competent Manager: A Model for Effective Performance. New York: Wiley \& Sons.

- (1983). «The Competent Manager: A Model for Effective Performance». Strategic Management Journal, 4(4): 385-387.

- (2006). «Intentional change theory from a complexity perspective». Journal of Management Development, 25(7): 607-623.

- (2007). "Competencies in the 21st century». Journal of Management Development, 27(1):5-12.

Boyatzis, R. E.; Goleman, D. and Rhee, K. (2000). «Clustering competence in emotional intelligence: Insights from the emotional competence inventory», in BAR-ON, R. and PARker, J. (2000). The Handbook of Emotional Intelligence. San Francisco: Jossey-Bass.

Boyatzis, R. E. and Saftcioglu, A. (2008). «A 20-year view of trying to develop emotional, social and cognitive intelligence competencies in graduate management education». Journal of Management Development, 27(1): 92108.

Boyatzis, R. E. and Sala, F. (2004). «Assessing emotional intelligence competencies», in Geher, G. (2004). The Measurement of Emotional Intelligence. Hauppauge: Novas Science Publishers.

Brackett, M. A. and Mayer, J. D. (2003). «Convergent, discriminant, and incremental validity of competing measures of emotional intelligence». Personality and Social Psychology Bulletin, 29: 1147-1158.

Brackett, M.A.; Rivers, S. E.; Shiffman, S.; Lerner, N. and Salovey, P. (2006). «Relating emotional abilities to social functioning* a comparison of self-report and performance measures of emotional intelligence». Journal of Personality and Social Psychology, 91: 780-795.

Cakan, M. and Altun, S. A. (2005). «Adaptation of an emotional intelligence scale for Turkish educators». International Education Journal, 6 (3):367-372.

Carmeli, A. (2003). «The relationship between emotional intelligence and work attitudes, behaviour and outcomes: an examination among senior managers». Journal of Managerial Psychology, 18(8): 788-813.

Chen, W*; Jacobs, R. and Spencer, L. (1998), "Calculating the Competencies of Stars», in Goleman, D. (1998). Working with Emotional Intelligence. New York: Bantam Books. 
Cherniss, C. (2001). «Emotional intelligence and organizational effectiveness», in Cherniss, C. and Goleman, D. (2001). The Emotionally Intelligent Workplace. San Francisco: Jossey-Bass.

Cherniss, C. y Adler, M. (2000). Promoting emotional intelligence in organizations. Alexandria, Virginia: ASTD.

Ciarrochi, J.V*; Chan, A. Y. C. and Caputi, P. (2000). «A critical evaluation of the emotional intelligence construct». Personality and Individual Differences, 28:539-561.

Danvila del Valle, I. and Sastre Castillo, M. A. (2010). «Inteligencia Emocional: una revisión del concepto y líneas de investigación». Cuadernos de Estudios Empresariales, 20: 107-126.

DAwdA, D. and HART, S. D. (2000). «Assessing emotional intelligence: Reliability and validity of the Bar-On Emotional Quotient Inventory (EQ-i) in university students». Personality and Individual Differences, 28: 797-812.

Davies, M.; Stankov, L. and Roberts, R. D. (1998). «Emotional intelligence; In search of an elusive construct». Journal of Personality and Social Psychology, 75(4): 989-1015.

Dulewicz, V. and Higgs, M. (1998). «Can emotional intelligence be measured and developed?». Leadership E Organization Development Journal, 20(5): $242-252$.

Dulewics, V. and Higgs, M. (2000). «Emotional intelligence: a review and evaluation study»+Journal of Managerial Psychology, 15(4):341-372.

- (2004). «Can emotional intelligence be developed?». Human Resource Management, 15(1): 95-111.

Edwards, A. III (2008). Competency modelling as an antecedent for effective leadership development and succession planning within the public social services environment. Fresno: Alliant International University.

FATT, J. P. (2002). «Emotional intelligence: implications for human resource managers». Management Research News, 25(11):57-74.

Gardner, H. (1983). Frames of Mind: The Theory of Multiple Intelligences. New York: Basic Books.

Gardner, H. (1993). Multiple intelligences: The theory in practice. New York: Basic Books.

Goldenberg, I.; Matheson, K. and Mantler, J. (2006). «The Assessment of Emotional Intelligence: A Comparison of Performance-Based and SelfReport Methodologies». Journal of Personality Assessment, 86(1):33-45.

Goleman, D. (1995). Emotional Intelligence. New York: Bantam Books.

- (1998a). «What makes a leader?». Harvard Business Review, 76: 93-104. 
- (1998b). Working with Emotional Intelligence. New York: Bantam Books.

- (2001). «Emotional intelligence: issues in paradigm building», in CHERniss, C. and Goleman, D. (2001). The Emotionally Intelligent Workplace. San Francisco: Jossey-Bass.

Gottramedon, L. S. (1998). "The general intelligence factor». Scientific American Presents Intelligence, 9: 24-29.

Higgs, M. and Rowland, D. (2002). «Does it need emotional intelligence to lead change?». Journal of General Management, 27:62-76.

Hochschild, A. R. (1983). The managed heart: Commercialization of human feelings. Berkeley: University of California press.

Hopkins, M. M. and Bilimoria, D. (2008). «Social and emotional competencies predicting success for male and female executives». Journal of Management Development, 27(1): 13-35.

Howard, A. and Bray, D. (1988). Managerial Lives in Transition: Advancing Age and Changing Times. Ney York: Guilford Press.

Jamali, D.; Sidani, Y. and Abu-Zaki, D. (2008). «Emotional intelligence and management development implications. Insights from the Lebanese context». Journal of Management Development, 27(3): 348-360.

Jordan, P.; Ashranasy, N. and Hartel, C. (2002). «Emotional intelligence as a moderator of emotional and behavioral reactions to job insecurity». Academy of Management Review, 27: 361-371.

Landy, F. J.; Shankster, L. J. y Kohler, S. S. (1994). «Personnel selection and placement». Annual Review of Psychology, 45: 261-296.

Law, K. S.; Wong, C. S.; Huang, G. y Li, X. (2008). «The effects of emotional intelligence on job performance and life satisfaction for the research and development scientists in China». Asia Pacific Journal Management, 25:51-69.

Law, K. S.; Wong, C.S. and Song, L. (2004). «The construct and criterion validity of emotional intelligence and its potential utility for management studies». Journal of Applied Psychology, 89(3): 483-496.

Leuner, B. (1966). «Emotional intelligence and emancipation». Praxis der Kinderpsychologie und Kinderpsychiatrie, 15: 193-203.

Levy-Leboyer, C. (1997). Gestión de las competencias. Cómo analizarlas, cómo evaluarlas, cómo desarrollarlas. Barcelona: Gestión 2000.

Longhorn, S. (2004). «How emotional intelligence can improve management performance». International Journal of Contemporary Hospitality Management, $16(4): 220-230$.

Luthans, F.; Hodgetts, R. M. and Rosenkrantz, S. A. (1988). Real Managers. Cambridge: Ballinger Press. 
Mandell, B. and Pherwani, S. (2003). «Relationship between emotional intelligence and transformational leadership style: a gender comparison». Journal of Business and Psychology, 17(3): 387-404.

Matthews, G.; Zeidner, M. and Roberts, R. (2002). Emotional intelligence: Science and myth? Cambridge: The MIT Press.

Mayer, J.D.; Carusso, D. R. and Salovey, P. (2000). «Emotional intelligence meets traditional standards for an intelligence». Intelligence, 27(4): 267-298.

Mayer, J. D. and Geher, G. (1996). «Emotional intelligence and the identification of emotion». Intelligence, 22(1): 89-113.

Mayer, J. D. and Salovey, P. (1997). "What is emotional intelligence?», in Salovey, P. and Sluyter, D. J. (1997). Emotional development and emotional intelligence: Educational implications. New York: Basic Books.

Mayer, J. D; Salovey, P. y Carusso, D. R. (2004). «Emotional Intelligence; Theory, Findings, and Implications». Psychological Inquiry, 15(3): 197-215.

McClelland, D. C. (1973). «Testing for Competence rather than for «Intelligence»». American Psychologist, 28: 1-14.

- (1998). «Identifying competencies with behavioral-event interviews». Psychological Science. 9(5):331-340.

Newsome, S.; Day, A. L. and Catano, V. M. (2000). "Assessing the predictive validity of emotional intelligence». Personality and Individual Differences, 29: 1005-1016.

Nikolaou, I* and Tsaousis, I. (2002). «Emotional intelligence and occupational stress». The International Journal of Organizational Analysis, 10(4)ः 327-342.

Nordhaug, O. and KJell, G. (1994). «Competences as resources in firms». The International Journal of Human Resource Management, 5(1):89-106.

Opengart, R. (2007). «Emotional Intelligence in the K-12 Curriculum and its Relationship to American Workplace Needs: A Literature Review». Human Resource Development Review, 6(4): 442-458.

O'Reilly III, C. A. and Chatman, J. A. (1994), «Working smarter and harder: A longitudinal study of managerial success». Administrative Science Quarterly, 39: 603-627.

PAyne, W. L. (1986). "A study of emotion: Developing emotional intelligence: Self-integration; relating to fear, pain and desire». Dissertation Abstracts International, 47(1), 203A.

Petrides, K.V. and Furnham, A. (2006). "The role of trait emotional intelligence in a gender-specific model of organizational variables». Journal of Applied Social Psychology, 36:552-569. 
Prati, L.; Douglas, C.; Ferris, G.; Ammeter, A. and Buckley, M. (2003). «Emotional intelligence, leadership effectiveness and team outcomes». The International Journal of Organizational Analysis, 11(1):21-40.

Punia, B. K. (2002). Emotional intelligence and leadership behavior in indian executives: an exploratory study. Hisar: Guru Jambheshwar University.

Roberts, R. D.; Zeidner, M. and Matthews, G. (2001). «Does emotional intelligence meet traditional standards for an intelligence? Some new data and conclusions ${ }$. Emotion, 1: 196-231.

Salovey, P. and Mayer, J. D. (1990). «Emotional intelligence». Imagination, Cognition and Personality, 9(3): 185-211.

- (1997). Educational Development and Emotional Intelligence. New York: Basic Books.

SANGHi, S. (2009). «Building Competencies»+ Industrial Management, 51(3): 14-17.

Shoikova, E. D. and Krumova, M. J. (2010). «Overview of the Occupational Information Network». Annual Journal of Electronics, 4(1)ः152-156.

Spencer, L. and Spencer, S. (1993). Competence at Work. New York: John Wiley.

Strang, K. D. (2007). «Examining effective technology project leadership traits and behaviors». Computers in Human Behavior, 23: 424-462.

Sutton, R. I. (1991). «Maintaining norms about expressed emotions: The case of bill collectors». Administrative Science Quarterly, 36: 245-268.

Thi, L. T. and Kirby, S. L. (2002). «Is Emotional Intelligence an Advantage? An Exploration of the Impact of Emotional and General Intelligence on Individual Performance». The Journal of Social Psychology, 142(1): 133-143.

Thorndike, E. L. (1920). «Intelligence and its uses». Harper's Magazine, 140: $227-235$.

Turner, R. and Lloyd-Walker, B. (2008). «Emotional intelligence (EI) capabilities training: can it develop EI in project teams?». International Journal of Managing Projects in Business, 1(4): 512-534.

Turner, J. R. and Müller, R. (2005). «The project manager's leadership style as a success factor on projects: a Literature Review». Project Management Journal, 36: 49-60.

Vakola, M.; Tsaousis, I. and Nikolaou, I. (2004), «The role of emotional intelligence and personality variables on attitudes toward organizational change». Journal of Managerial Psychology, 19(2): 88-110.

VAN Der ZEe, K. (2004). «Is trait-emotional intelligence simply or more than just a trait?». European Journal of Personality, 18: 243-263. 
Van Ghent, D. (1961). The English novel: Form and function. New York: Harper \& Row.

Van Rooy, D. L. and Viswesvaran, C. (2003). «Emotional intelligence: a metaanalytic investigation of predictive validity and nomological net». Journal of Vocational Behavior, 65(1): 71-95.

Van Rooy, D. L.; Viswesvaran, C. and Pluta, P. (2005). «An Evaluation of Construct Validity: What Is This Thing Called Emotional Intelligence?». Human Performance, 18(4): 445-462.

Velasco Estudillo, M. N. (2009). «Modelo de competencias colaborativas para la transferencia de conocimiento», Tesis (Doctorado en Ciencias Administrativas) - Instituto Tecnológico y de Estudios Superiores de Monterrey, Campus Ciudad de México.

Voola, R.; Carlson, J. and West, A. (2004). «Emotional intelligence and competitive advantage: examining the relationship from a resource-based view». Strategic Change, 13(2): 83-93.

WATKIN, C. (2000). «Developing emotional intelligence». International Journal of Selection and Assessment, 8(2): 89-92.

Weisinger, H. (1998). Emotional Intelligence at Work. San Francisco: JosseyBass.

White, R. (1959). «Motivation reconsidered: The concept of competence». Psychological Review, 66(5): 297-333.

Wolff, S. B.; Pescosolido, A. T. and Druskat, V. U. (2002). «Emotional intelligence as the basis of leadership emergence in self-managing teams». The Leadership Quarterly, 13(5): 502-522.

Wong, C. S. and Law, K. S. (2002). "The effects of leader and follower emotional intelligence on performance and attitude: An exploratory study». The Leadership Quarterly, 13: 243-274.

- (2005). «The interaction effect of emotional intelligence and emotional labor on job satisfaction: A test of Holland's classification of occupations», in Härtel, C. E. J.; Zerber, W. J. and Ashranasy, N. M. (2005). Emotions in Organizational Behavior. Mahwah: Lawrence Erlbaum Associates. 